Gut, 1981. 22, 529-533

\title{
Gastric mucosal blood flow and acid secretory changes in man with impromidine: a new specific histamine- $\mathrm{H}_{2}$-receptor agonist
}

\author{
R L MCISAAC,* B J JOHNSTON, AND L P FIELDING \\ From The Academic Surgical Unit, St. Mary's Hospital Medical School, London
}

SUMMARY The effect of impromidine, a new histamine- $\mathrm{H}_{2}$-receptor agonist, on gastric mucosal blood flow (neutral red clearance) and acid secretion was studied in nine volunteers. Impromidine stimulated a dose-dependent increase in neutral red clearance and acid secretion. Simultaneous cimetidine in three doses caused a parallel shift to the right for both acid output and clearance with unchanged maxima compatible with simple surmountable antagonism. There were small cardiovascular changes: an increased heart rate with a decreased diastolic pressure during infusion of impromidine. These changes were antagonised by cimetidine.

The involvement of histamine in the control of gastric acid secretion was supported by the discovery of the specific inhibitors of $\mathrm{H}_{2}$-receptors on the parietal cell. ${ }^{1}$ Studies in animals have also shown that the gastric vasculature is sensitive to histamine through a combination of $\mathrm{H}_{1^{-}}$and $\mathrm{H}_{2}-$ receptors although with different relative contributions. $^{2}$ " In man histamine stimulates a dosedependent increase in both acid secretion and mucosal blood flow but the blood flow component is relatively resistant to inhibition by cimetidine. ${ }^{4}$ A specific histamine- $\mathrm{H}_{2}$-receptor agonist would be of value in the investigation of the role of histamine in the control of gastric acid secretion and blood flow in both healthy man and in patients with peptic ulcer disease. Recent studies have indicated that impromidine is a potent stimulant of gastric secretion in man with relatively fewer side-effects than histamine. ${ }^{5} 6$ The purpose of the present investigation was to study the stimulation of acid secretion and blood flow in healthy volunteers using increasing doses of impromidine and to compare these effects with our previous results using histamine. ${ }^{4}$

\section{Methods}

In the study group there were nine volunteers, mean age 22 years (range 21-26 years). The study

*Address for correspondence: Dr R L Mclsaac, Academic Surgical Unit, St. Mary's Hospital Medical School, London W2 I PG.

Received for publication 11 December 1980 was approved by the local ethical committee and informed written consent was obtained from each volunteer in accordance with the Declaration of Helsinki.' Gastric mucosal blood flow was measured by the neutral red clearance technique. ${ }^{8}$


intubated with a double lumen nasogastric tube (Sherwood 12-14 French gauge), the position being determined by a water recovery test. ${ }^{*}$ Overnight secretion was aspirated and discarded. A 15 minute basal sample was collected as a reference for neutral red standards (see below). Winged needles were inserted into a vein in each forearm; one for drug infusion and the other for blood sampling. A $15 \mathrm{ml}$ venous sample was taken for processing of neutral red standards in whole blood and then a loading dose of neutral red (NR, $125 \mu \mathrm{g} / \mathrm{kg}$ ) was given followed by a constant infusion $(250 \mu \mathrm{g} / \mathrm{kg}$ per $\mathrm{h})$. Blood samples were taken at 15 minute intervals for 45 minutes and then at 30 minute intervals thereafter. After a basal period (45 minutes) gastric acid secretion was stimulated by an infusion of impromidine. Doseresponse curves were constructed on two separate days at least one week apart. On day one, impromidine was given in four sequential doses $(1 \cdot 25,2 \cdot 5,5 \cdot 0$, and $10 \mu \mathrm{g} / \mathrm{kg}$ per $\mathrm{h})$ each for one hour (Fig. 1). Two volunteers received impromi- 


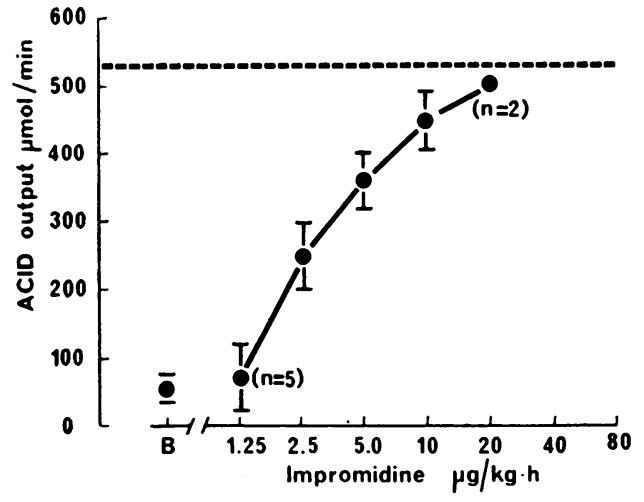

Fig. I Mean (: $S E M$ ) acid output in volunteers during infusion of graded doses of impromidine (1-25-20) $\mu g / k g$ per $h$ ). Basal secretion (B) $54 \cdot 4+13 \cdot 3 \mu \mathrm{mol} / \mathrm{min}$ has been subtracted. The theoretical maximum nas calculated to be $530+60.5 \mu \mathrm{mol} / \mathrm{min}$ and is show'n by' the dotted line.

dine in the dose range $2.5-20 \mu \mathrm{g} / \mathrm{kg}$ per $\mathrm{h}$. On day two, the test was repeated with cimetidine $(0 \cdot 25$, 0.5 , or $1.0 \mathrm{mg} / \mathrm{kg}$ ) which was randomised among three groups of the volunteers (three, three, and two volunteers respectively). The infusion of cimetidine was begun 30 minutes before impromidine (dose-range 5-80 $\mu \mathrm{g} / \mathrm{kg}$ per $\mathrm{h}$ ).

Gastric juice was collected every 10 minutes. The volume of the aspirate was recorded and the concentration of $\mathrm{H}^{+}$measured by titration of $3 \mathrm{mI}$ gastric juice to $\mathrm{pH} 7.0$ with $0 \cdot 1 \mathrm{M} \mathrm{NaOH}$ using an automatic titrator (Radiometer, Copenhagen). Acid secretion was expressed as $\mu \mathrm{mol} \mathrm{H}^{+} / \mathrm{min}$. NR concentration was determined in $3 \mathrm{ml}$ blood and $1 \mathrm{ml}$ gastric juice after alkalinisation and extraction into diethyl ether $(10 \mathrm{ml}$ Analar grade, BDH Ltd) with further extraction into $0.1 \mathrm{M}$ $\mathrm{HCl}$. The aqueous layer was read in a spectrophotometer (Pye-Unicam SP 1800) at $540 \mathrm{~nm}$ against serial standards of NR made up in whole blood or gastric juice and processed along with the samples. Neutral red clearance (NRC) in $\mathrm{ml} / \mathrm{min}$ was calculated from the equation $\mathrm{NCR}=$ $(\mathrm{NR})_{\mathrm{s}} \times \mathrm{V} /(\mathrm{NR})_{\mathrm{b}}$, where $(\mathrm{NR})_{\mathrm{s}}$ and $(\mathrm{NR})_{\mathrm{b}}$ are gastric and whole blood concentrations of NR and $\mathrm{V}$ is the volume of gastric aspirate in $\mathrm{ml} / \mathrm{min}$.

Dose-response curves were constructed using the mean of the last two 10 minute periods at each dose level of impromidine. The data were used to fit non-linear curves by the method of least squares ${ }^{10}$ so as to calculate a best fit maximum for acid secretion and NCR as well as obtaining calculated values for the dose of impromidine producing a half-maximal response

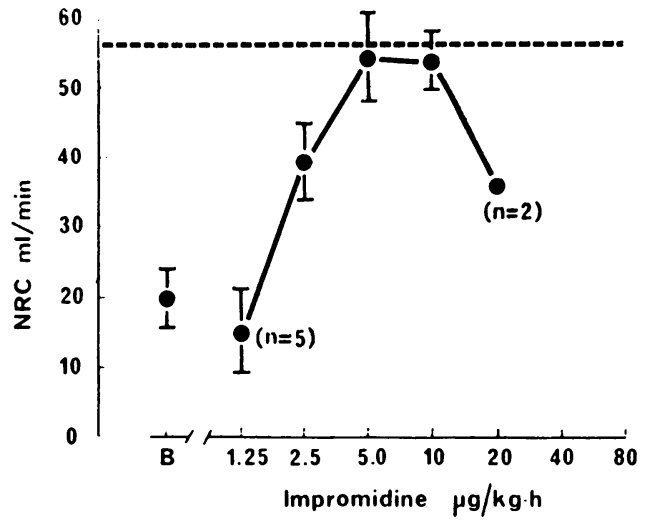

Fig. 2 Mean( $\pm S E M$ ) neutral red clearance in the same volunteers as in Fig. I. Basal NRC (B) $20+4 \cdot 3$ $\mathrm{ml} / \mathrm{min}$ has been subtracted. The calculated maximum was 56 !.9.6 ml/min and is shown by the dotted line.

$\left(E D_{5,1}\right)$ and an inhibitory dose $e_{50}\left(\mathrm{ID}_{30}\right)$ for cimetidine. Standard errors for these calculations were also derived from the least squares fit.

Blood pressure and heart rate were measured electronically by inflating a cuff around the arm over the brachial artery (Digital 8000. Ueda Electronics Ltd) and changes were analysed by means of Student's paired $t$ test.

\section{Results}

I MPROMII) INE DOSE-RESPONSE

STU I I ES

Impromidine (1.25-10 $\mu \mathrm{g} / \mathrm{kg}$ per $\mathrm{h})$ caused a dcse-dependent increase in both acid output and NRC (Figs 1 and 2). In the two volunteers who received an infusion of impromidine $20 \mu \mathrm{g} / \mathrm{kg}$ per $\mathrm{h}$, this dose caused a small increase in acid output above that induced by $10 \mu \mathrm{g} / \mathrm{kg}$ per $\mathrm{h}$, but NRC at the high dose began to decrease. The best fit curves for these data give the following calculated values (omitting the data for 20 $\mu \mathrm{g} / \mathrm{kg}$ per $\mathrm{h}$ ). Maximal acid ouput was $530 \pm 60.5$ (SEM) $\mu \mathrm{mol} \mathrm{H}^{+} / \mathrm{min}$ and the $\mathrm{ED}_{50} 2.3 \pm 0.26$ $\mu \mathrm{g} / \mathrm{kg}$ per $\mathrm{h}$. For NRC the calculated maximal rate was $56 \pm 9.6 \mathrm{ml} / \mathrm{min}$ and the $E_{50}, 1 \cdot 7 \pm 0.34$ $\mu \mathrm{g} / \mathrm{kg}$ per $\mathrm{h}$.

EFFECT OF CIMETIDINE ON

I MPROMII) INE-INI) (' ( E I) A ( I I)

SECRETION AND NRC: COMPARISON WITH PREVIOUS HISTAMINE DATA In a previous study, cimetidine $(0.6 \mathrm{mg} / \mathrm{kg}$ per h) reduced acid secretion induced by histamine but had no effect on neutral red clearance. 


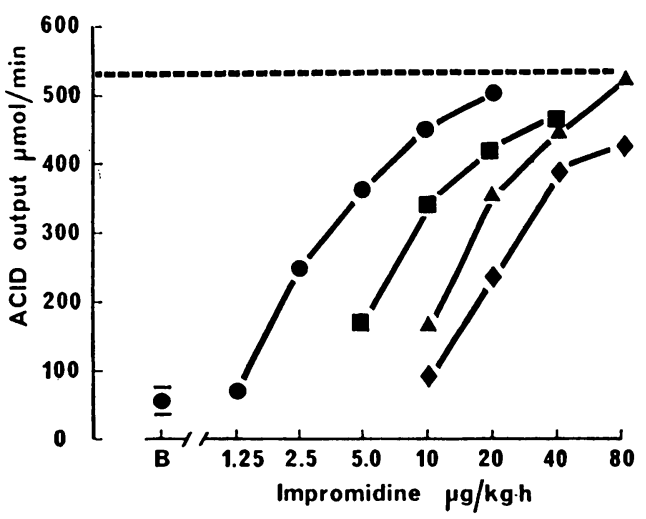

Fig. 3 The effect or cimetidine given in three doses $0 \cdot 25$ ( $), 0 \cdot 5(\Delta)$, and $1 \cdot 0(\diamond) \mathrm{mg} / \mathrm{kg}$ per h on impromidineinduced gastric acid secretion. The calculated $I D_{50}$ for cimetidine inhibition was $0 \cdot 10 \pm 0.014 \mathrm{mg} / \mathrm{kg}$ per $\mathrm{h}$.

In the present study cimetidine caused a parallel, dose-dependent displacement of the curves for both acid secretion and NRC to the right (Fig. 3, Table). The data are also tabulated for comparison of the effect of cimetidine on both histamine- and impromidine-induced acid secretion and NRC (Table). On a molar basis impromidine is some five times more potent than histamine on acid output and NRC. The calculated ID $_{50}$ for cimetidine-inhibition of acid secretion was the same whether histamine or impromidine was used as stimulant but the effects on NRC differed.

\section{C: ARDIO VASCULAR EFFECTS OF}

I M P R O M I D I N E

During the infusion of impromidine $(5$ and 10 $\mu \mathrm{g} / \mathrm{kg}$ per $\mathrm{h}$ ) there was an increase in pulse rate of $12 \pm 3$ beats per minute and this was statistically different from the pretreatment periods or the lower doses of impromidine $(P<0.05)$. This increase in pulse rate was accompanied by a

Table Values for dose of agonist producing half maximal rates $\left(E D_{50}\right)$ for impromidine and histamine on acid secretion and neutral red clearance (NRC) and inhibitory dose ${ }_{50}\left(I D_{50}\right)$ for cimetidine against these agonists

\begin{tabular}{llc}
\hline & Impromidine & Histamine \\
\hline ED $_{50}(\mu \mathrm{g} / \mathrm{kg}$ per $\mathrm{h})$ & & \\
ACID & $2 \cdot 3 \pm 0.213$ & $11 \cdot 1+2 \cdot 15$ \\
NRC & $1 \cdot 7+0.339$ & $7 \cdot 9+1 \cdot 27$ \\
ID $50(\mathrm{mg} / \mathrm{kg}$ per $\mathrm{h})$ & & \\
ACID & $0 \cdot 10+0.014$ & $0 \cdot 3 \pm 0.15$ \\
NRC & $0 \cdot 10 \pm 0.027$ & No effect \\
\hline
\end{tabular}

The data for histamine are taken from Knight et al.4 + Cimetideine $0.6 \mathrm{mg} / \mathrm{kg}$ per $\mathrm{h}$ had no effect on the histamine-induced NRC.

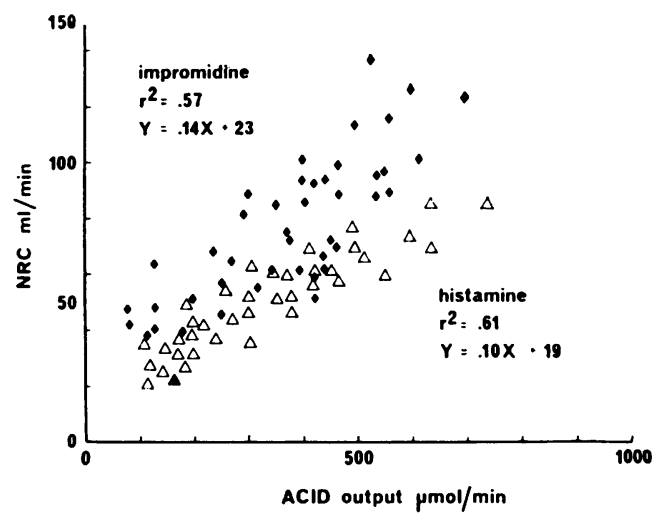

Fig. 4 Comparison of the acid secretory and NRC responses during infusion of graded doses of histamine $(\Delta)$ and impromidine $(\diamond)$. The calculated regression line for histamine was $Y=0 \cdot 10 X+19, r^{2}=0 \cdot 61, n=38$ $(\mathrm{P}<0.001)$ and for impromidine $Y=0.14 X+23$, $r^{2}=0.57, n=44(\mathrm{P}<0.001)$.

decrease in diastolic pressure of $12 \pm 4: 1 \mathrm{~mm} \mathrm{Hg}$ $(\mathrm{P}<0.05$ compared with resting levels). Only small changes in systolic pressure were seen, so that the mean arterial blood pressure fall from $92 \pm 3 \cdot 3 \mathrm{~mm} \mathrm{Hg}$ to $80 \pm 2 \cdot 3 \mathrm{~mm} \mathrm{Hg}$ was due entirely to the above changes in diastolic pressure. Concomitant infusion of cimetidine prevented these changes but the cardiovascular responses reappeared at higher doses of impromidine 20,40 , and $80 \mu \mathrm{g} / \mathrm{kg}$ per $\mathrm{h}$.

Relationship between NRC and acid secretion during impromidine and histamine infusion

There .was a significantly linear relationship between neutral red clearance and acid output during impromidine infusion and this is compared with histamine infusion (Fig. 4). The intercepts of the two regression lines were not different but there was a difference in slopes (slope $\pm 95 \%$ confidence limits: impromidine $0.14 \pm 0.06$ and histamine $0.10 \pm 0.04, \mathrm{P}<0.05$ ), impromidine producing a higher NRC relative to secretion than histamine.

\section{Discussion}

In 1966, Jacobson, Linford, and Grossman ${ }^{11}$ described the use of aminopyrine clearance for the estimation of gastric mucosal blood flow. Since that time experience with the clearance markers has provided evidence that mucosal blood flow and acid secretion are in some way linked, although this relationship is not entirely clear. ${ }^{12}$ In addition, some limitations to the use 
of clearance markers have been uncovered (although perhaps not widely recognised by those who use such agents) and have prompted more sceptical interpretations of results. ${ }^{13-15}$ An element of uncertainty remains that the clearance markers may not accurately reflect mucosal blood flow during low secretory rates or when there are rapid changes in flow. It is important to keep this in mind when studies are confined to man and where other methods are not yet available for comparison. ${ }^{1616}$

The newest clearance marker, neutral red, has been used in both animals and in man. ${ }^{8}$ In animals during brisk acid secretion blood flow as estimated by neutral red clearance is of the same order as that using other methods. ${ }^{12} \mathrm{We}$ have used the clearance of neutral red to estimate gastric mucosal blood flow in man during stimulation of acid secretion by the new agent, impromidine, which acts specifically at the histamine- $\mathrm{H}_{2}$-receptor. Impromidine increased neutral red clearance in a dose-dependent manner in addition to its previously described effect to increase acid secretion. ${ }^{5}$ As expected, the $\mathbf{H}_{2}$ receptor antagonist cimetidine produced a parallel shift to the right of the dose-response curves for both acid secretion and NRC but did not change the maximum. This agrees with our previous studies in the dog in which cimetidine and ranitidine inhibited NRC and acid secretion to both histamine and impromidine. ${ }^{8}$ However, in man, cimetidine had no effect on the NRC response to histamine while reducing the secretory response. ${ }^{4}$ Initially, this suggested to us that the vasculature was less sensitive than the parietal cell to cimetidine and that the unchanged response of the vasculature during infusion of cimetidine was due to residual stimulation of $\mathrm{H}_{1}$-receptors by histamine. However, in that study the histamine- $\mathrm{H}_{1}$-receptor antagonist, mepyramine, also failed to alter the vascular response to histamine. The study with impromidine and cimetidine reported here indicated that the above suggestion is untenable and that the sensitivity of the vasculature is probably not different from that of the parietal cell, although the relationship between the two is still not completely clear. The effect of histamine on the parietal cell is undoubtedly via stimulation of the $\mathrm{H}_{2}$-receptor but the response of the vasculature is more complex. The increased blood flow seen with histamine may reflect partly the energy requirements of increased acid secretion and partly a direct interaction with histamine- $\mathrm{H}_{1}$ and $\mathrm{H}_{2}$-receptors on the vasculature. Using more direct methods in animals the histamine-induced vasodilatation in the mesenteric vascular beds has been described as biphasic and time-dependent-the $\mathrm{H}_{1}$-response characterised as immediate but short lived and the $\mathrm{H}_{2}$-response as slow in onset and of longer duration. ${ }^{2}$ More difficult to understand is the fact that the $\mathrm{H}_{1}$-antagonists can actually increase histamine-induced blood flow and acid secretion in some animals and perhaps in man. ${ }^{12}$ Two explanations for this are possible: first an inhibitory action of the $\mathbf{H}_{\mathbf{1}}$-receptor on the gastric vasculature to restrain blood flow and hence secretion; second, the systemic hypotensive action of histamine which leads to a reduction in splanchnic blood flow may limit the gastric mucosal blood flow and secretory responses to histamine. ${ }^{17}$ In either case, inhibition of the $\mathrm{H}_{1}$-mediated effects of histamine or use of a specific $\mathrm{H}_{2}$ agonist would then allow unfettered blood flow and secretion. In the present study in man a comparison of the blood flow responses to histamine with those of impromidine showed that for the same level of acid secretion histamineinduced blood flow was less. Also in another study in $\operatorname{man}^{18}$ again using neutral red clearance we found that pentagastrin-induced blood flow was greater than histamine-induced flow and that both cimetidine and ranitidine inhibited these responses to pentagastrin. It may be that blood pressure changes whieh occur on infusion of histamine in animals and in man but which are less marked with impromidine or pentagastrin', ${ }^{19-21}$ could account for the lesser blood flow, but clearly histamine-mediated responses of the vasculature are complex in man. The specific $\mathrm{H}_{2}$-receptor agonist, impromidine, has some advantages over histamine as a potent gastric secretogogue in healthy man, producing readily definable acid secretory and vascular responses which can be competitively inhibited by cimetidine. Thus, it may have a place in the routine testing of gastric function in patients with peptic ulcer diseases and will also be useful for the study of mechanisms of gastric acid secretion and mucosal blood flow in these patients.

We gratefully acknowledge the Research Institute, Smith, Kline and French Laboratories Limited, Welwyn Garden City, Herts, for the gifts of impromidine and cimetidine and for financial support for the project.

\section{References}

${ }^{1}$ Black JW, Duncan WAM, Durant CJ, Ganellin CR, Parsons ME. Definition and antagonism of hista- 
mine $\mathrm{H}_{2}$-receptors. Nature 1972; 236:385-90.

2 Owen DAA, Harvey CA, Johnston BM, Shaw KD. Histamine-induced increase in gastric blood flow in cats: Comparison of findings with different experimental techniques. In: Fielding LP, ed. Gastrointestinal mucosal blood flow. Edinburgh: Churchill Livingstone, 1980: 125-46.

${ }^{3}$ Pawlik W, Tague LL, Tepperman BL, Miller TA, Jacobson ED. Histamine $\mathrm{H}_{1}$-and $\mathrm{H}_{2}$-receptor vasodilatation of canine intestinal circulation. $A m \mathrm{~J}$ Physiol 1977; 233:E219-24.

${ }^{4}$ Knight SE, McIsaac RL, Rennie CD. The effect of histamine and histamine antagonists on gastric acid secretion and mucosal blood flow in man. Br J Surg $1980 ; 67: 266-8$.

${ }^{5}$ Hunt RH, Mills JG, Beresford J, Billings JA, Burland WL, Milton-Thompson GJ. Gastric secretory studies in humans with impromidine (SK\&F 92676)-a specific histamine $\mathrm{H}_{2}$-receptor agonist. Gastroenterology 1980; 78:505-11.

${ }^{6}$ Mills JG, Hunt RH, Bangerter $U$, Halter F, Burland WL, Milton-Thompson GJ. The effects of Impromidine, a specific $\mathrm{H}_{2}$-receptor agonist, on gastric secretion in man. In: Torsoli A et al., eds. European symposium on further experience with $\mathrm{H}_{2}$-receptor antagonists in peptic ulcer disease and progress in histamine research. Capri, October 1979. Amsterdam: Excerpta Medica 1980:264-70.

${ }^{7}$ Declaration of Helsinki, Human Experimentation. Code of ethics of the World Medical Association. Br Med J 1964; 2:177.

${ }^{8}$ Knight SE, McIsaac RL, Rennie CD, Flannery MC, Fielding LP. Studies of gastric mucosal blood flow: neutral red clearance and dose-response curve analysis. In: Fielding LP, ed. Gastro-intestinal mucosal blood flow. Edinburgh: Churchill Livingstone, 1980: 105-24.

${ }^{9}$ Hassan MA, Hobsley M. Positioning of subject and of nasogastric tube during a gastric secretion study. Br Med J 1970; 1:456-60.

${ }^{10}$ Waud DR. Analysis of dose-response curves. In: Daniel EE, Paton DM, eds. Methods in pharmacology. New York: Plenum Press, 1975: Chap. 27.

11 Jacobson ED, Linford RH, Grossman MI. Gastric secretion in relationship to mucosal blood flow studied by a clearance technic. J Clin Invest 1966; 45:1-13.

${ }_{12}^{2}$ McIsaac RL. Mucosal blood flow in gastric physiology. In: Fielding LP, ed. Gastro-intestinal mucosal blood flow. Edinburgh: Churchill Livingstone, 1980: 147-56.

1:Davenport HW, Munro D. Aminopyrine clearance in the damaged gastric mucosa: reconciliation of conflicting data. Gastroenterology 1973; 65:512-4.

${ }^{14}$ Moody FG. The basis of the methods to estimate mucosal blood flow. In: Fielding LP, ed. Gastrointestinal mucosal blood flow. Edinburgh: Churchill Livingstone, 1980: 83-6.

${ }^{15}$ Sonnenberg A, Blum AL. Limitations to measurement of gastric mucosal blood flow by 14-C-aminopyrine clearance. In: Fielding LP, ed. Gastrointestinal blood flow. Edinburgh: Churchill Livingstone, 1980: 43-58.

1 "Ivarsson LE, Darle $\mathrm{N}$, Hulten L, Lindhagen J, Lundgren $O$. Gastric blood flow in man: $85-\mathrm{Kr}$ elimination technique. In: Fielding LP, ed. Gastrointestinal mucosal blood flow. Edinburgh: Churchill Livingstone, 1980: 89-93.

1iJacobson ED. Physiologic aspects of the intestinal circulation. In: Boley SJ, Schwartz S, Williams LF, eds. Vascular disorders of the intestine. New York: Appleton-Century-Crofts, 1971: 19-24.

${ }^{18}$ McIsaac RL, Johnston BJ, Fielding LP. Gastric mucosal blood flow in gastric secretory disorders: Effect of therapeutic agents. In: Konturek SJ, ed. Workshop on the pharmacology of the gastric mucosa. XI International Congress of Gastroenterology, Hamburg, July 1980. Stuttgart: Georg Thieme. (In press.)

${ }^{19}$ Durant GJ, Duncan WAM, Ganellin CR, Parsons ME, Blakemore RC, Rasmussen AC. Impromidine (SK\&F 92676) is a very potent and specific agonist for histamine- $\mathrm{H}_{2}$-receptors. Nature 1978; 276:403-5.

${ }^{20}$ Boyce MJ, Owen DAA, Wareham K. Modification of cardiovascular effects of histamine infusions in man by chlorpheniramine and cimetidine. $\mathrm{Br} J$ Pharmacol 1980; 70:110P.

${ }^{21}$ Boyce MJ, Balasubramanian V, Wareham $\mathbf{K}$. Cardiovascular effects in man of impromidine, a novel and specific histamine $\mathrm{H}_{2}$-receptor agonist. Br J Pharmacol 1980; 70:157P. 